\title{
Alteration of hepatic anti-oxidant systems by 4-nonylphenol, a metabolite of alkylphenol polyethoxylate detergents, in Far Eastern catfish Silurus asotus
}

\author{
Kwan Ha Park \\ Department of Aquatic Life Medicine, College of Ocean Science and Technology, Kunsan National University Gunsan, Korea
}

\begin{abstract}
Objectives This study aimed to estimate the effects of 4-nonylphenol (NP), a ubiquitously present surfactant in aquatic environments, on the anti-oxidant systems of the liver in the Far Eastern catfish Silurus asotus.

Methods Changes in biochemical parameters involved in glutathione (CSH)-related and other anti-oxidant systems were analyzed following 4 weeks of 4-NP administration (0.1 and $1.0 \mathrm{mg} / \mathrm{kg}$ diet) via a formulated diet to catfish.

Results 4-NP exposure induced an elevation in hepatic lipid peroxide levels and an accompanying decrease in reduced state GSH after 2 weeks, suggesting pro-oxidant effects of the chemical in catfish. This oxidative stress was associated with an inhibition of the GSH-utilizing enzyme glutathione peroxidase at the same time point. This inhibition was restored after 4 weeks. The activities of other anti-oxidant enzymes, i.e., glutathione reductase, superoxide dismutase and catalase were increased after 4 weeks. These enzyme increases occurred more strongly at the higher 4 -NP concentration $(1.0 \mathrm{mg} / \mathrm{kg}$ diet).

Conclusions 4-NP given to catfish at 0.1 to $1.0 \mathrm{mg} / \mathrm{kg}$ diet, concentrations relevant to environmental levels, depletes the endogenous anti-oxidant molecule GSH and temporarily inhibits $\mathrm{CSH}$-related anti-oxidant enzymes. Such declines in anti-oxidant capacity and elevated oxidative stress seem to be compensated eventually by subsequent activation of various anti-oxidant enzyme systems.
\end{abstract}

Keywords Anti-oxidant enzymes, Far Eastern catfish Silurus asotus, Glutathione, 4-Nonylphenol

\section{Introduction}

4-Nonylphenol (4-NP) is a typical endocrine disruptor which originates as a result of the microbial metabolism of nonylphenol polyethoxylates that are widely used as surfactants $[1,2]$. The large volume of production and use of surfactants has led to widespread release into the aquatic environment [3]. Although 4-NP is the degradation product of surfactants, this metabolite is more toxic than its parent compound and degradation proceeds very slowly in aquatic environments. The physicochemi-
Correspondence: Kwan Ha Park 558 Daehak-ro, Gunsan 573-701, Korea Tel: $+82-63-469-1885$

Fax: $+82-63-463-9493$

E-mail: khpark@kunsan.ac.kr

Received: April 23, 2015

Accepted: May 282015

Published online: July 2, 2015

This article is available from: http://e-eht.org/ 
Through docking studies with enzymes, Jayakanthan et al. [9] observed that anti-oxidant enzymes such as catalase (CAT) and superoxide dismutase (SOD) were strongly inhibited by 4-NP in the embryo. In Arabidopsis thaliana, a weed plant, 4-NP stimulates lipid peroxidation in leaves along with the induction of anti-oxidant enzymes such as ascorbate peroxidase, CAT, and SOD [10]. It has also been reported that 4-NP interferes with male reproductive function in mammals by producing ROS $[11,12]$. All these data obtained from different organisms collectively suggest that 4-NP might influence endogenous antioxidant systems in fish. Studies that have examined the toxicity of 4-NP in fish species are generally rare, and furthermore those on anti-oxidant systems are almost absent. Most of the ecological studies on 4-NP in fish have been limited to endocrine systems.

In view of the ubiquitous presence and ecotoxicological significance of 4-NP in aquatic environments, an assessment of the influence of this contaminant on the hepatic anti-oxidant systems of the Far Eastern catfish Silurus asotus was performed in this study. This specific catfish species is indigenous to Far Eastern Asian countries including Korea, China, Taiwan and Japan. As it is very well-known that 4-NP is widely present in most of the aquatic environments of Korea, the assessment of the adverse effects of this contaminant is highly meaningful. The significance of the observations reported in this study may be further highlighted by the fact that 4-NP levels used range within environmentally relevant low concentrations.

\section{Materials and Methods}

\section{Experimental Fish and Chemicals}

Far Eastern catfish were purchased from a local fish farm in Jeonbuk Province, Korea. Catfish were acclimatized under laboratory conditions maintained at $23 \pm 2^{\circ} \mathrm{C}$ under a $12: 12$ hours light/dark cycle. During acclimatization, fish were fed a basal diet (control diet in Table 1 ) twice daily at $2 \%$ body weight equally divided at 10:30 am and 4:30 pm. After acclimatization, fish of similar sizes (12 to $14 \mathrm{~g}$ ) were selected for exposure ex- periments. The test aquaria (370-liter capacity rectangular tank composed of fortified reinforced fiber) were supplied with aerated and dechlorinated continuous flow-through water (flow rate $=8 \mathrm{~L} / \mathrm{min}$ ). Sixty fish for each concentration level were used and 10 fish were sampled for biochemical analysis at weeks 0,2 , and 4 after exposure. For data not requiring fish euthanization (e.g., body weight measurement), all remaining fish at designated time points were used. Prior to euthanization, fish were anesthetized with neutralized MS-222 (Sigma-Aldrich, St. Louis, MO, USA). All procedures for fish handling were performed according to the Ethical Codes for Animal Experiments of Kunsan National University. Most of the other major chemicals were obtained from Sigma-Aldrich.

\section{Diet Preparations}

Experimental diets (Table 1) were formulated as described by Kim et al. [13] for this catfish species and 4-NP (CAS No. 10440-5, Sigma-Aldrich, >98\%) was supplemented at 0.1 and 1.0 $\mathrm{mg} / \mathrm{kg}$ diets. For this, 4-NP was first dissolved in absolute ethyl alcohol before mixing with a feed mixer. The mixture was extruded while moist through a 3-mm diameter extrusion module. The resulting pellets were freeze-dried to a moisture content of about $8.0 \%$. Pellets were crumbled into particles, sieved to obtain appropriate sizes and stored at $-70^{\circ} \mathrm{C}$ until fed. The control diet contained (in \%): white fish meal 40, casein 13, beef tallow 5, corn oil 5, dextrin 27, $\alpha$-cellulose 5.5, vitamin mix 2 , mineral mix 2 and choline chloride 0.6 [13]. As the 4-NP content constituted a small portion of the diet, i.e., $0.01-0.1 \mathrm{mg} / 100$ $\mathrm{g}$ diet in the 4-NP exposure groups, 4-NP was added to the control diet without further composition adjustments.

\section{General Assessment of Toxic Signs}

For the general assessment of toxic signs, mortality and body weight changes were measured during exposure at the indicated time points. Instantaneous maximum food intake was assessed by supplying the feed at two-fold the expected satiation level and unconsumed pellets was retrieved for weighing. The hepatosomatic index (HSI) was defined as the wet weight ratio be-

Table 1. Effects of 4-nonylphenol (4-NP) administration on survival, body weight, hepatosomatic index (HSI) and feed intake in Far Eastern catfish

\begin{tabular}{|c|c|c|c|c|c|c|c|c|}
\hline \multirow{2}{*}{ Group } & \multirow{2}{*}{$\begin{array}{c}\text { Fish no. of } \\
\text { at start }\end{array}$} & \multirow{2}{*}{ Death } & \multirow{2}{*}{$\begin{array}{l}\text { 4-NP intake } \\
(\mu \mathrm{g} / \mathrm{kg} / \mathrm{d})\end{array}$} & \multicolumn{3}{|c|}{ Body weight (g) } & \multirow{2}{*}{ HSI (\%) } & \multirow{2}{*}{$\begin{array}{l}\text { Food intake } \\
\text { (mg/head) }\end{array}$} \\
\hline & & & & Initial $(n=60)$ & 2 wk $(n=50)$ & 4 wk $(n=39-40)$ & & \\
\hline Control & 60 & $0 / 60$ & 0 & $12.2 \pm 1.6$ & $14.7 \pm 0.9$ & $18.4 \pm 1.3$ & $0.65 \pm 0.09$ & 533 \\
\hline $0.1 \mathrm{mg} / \mathrm{kg}$ diet & 60 & $1 / 60$ & 2 & $13.4 \pm 1.2$ & $15.3 \pm 1.3$ & $17.2 \pm 2.1$ & $0.61 \pm 0.18$ & 489 \\
\hline $1.0 \mathrm{mg} / \mathrm{kg}$ diet & 60 & $0 / 60$ & 20 & $13.2 \pm 1.5$ & $14,1 \pm 1.1$ & $15.3 \pm 1.1^{*}$ & $0.62 \pm 0.08$ & 516 \\
\hline
\end{tabular}

Significance was tested only for body weight changes and HSI. Food intake was assessed just before fish euthanization for the week 4 fish samples. Daily intake of 4-NP was calculated from the nominal 4-NP concentration in diet and the daily rat ion rate of $2.0 \%$ of the body weight. No significant change was noted in HSI $(n=10)$, nor in instantaneous food intake $(n=29-30)$; both of these parameters were assessed at the termination of exposure.

${ }^{*} p<0.05$. 
tween the hepatopancreas and whole body weight.

\section{Preparation of Liver Tissues for Biochemical Analysis}

At designated time points, livers were excised from anesthetized fish. The liver was then homogenized in four to five volumes of ice-cold tris buffer $(50 \mathrm{mM}, 1 \mathrm{mM}$ EDTA, $1 \mathrm{mM}$ dithiothreitol, $150 \mathrm{mM} \mathrm{NaCl}, \mathrm{pH} 7.5$ ) with several passes in a tissue homogenizer (X520; Ingenieurbüro CAT, Staufen, Germany). The homogenate was centrifuged $(12000 \times \mathrm{g}$ for $15 \mathrm{~min}-$ utes, Hanil, Seoul, Korea) at $3^{\circ} \mathrm{C}$ and the supernatant was used for assays.

\section{Lipid Peroxidation Levels}

Levels of thiobarbituric acid-reactive substances (TBARS) were measured to estimate hepatic malondialdehyde (MDA) concentration by the method described by Ohkawa et al. [14]. An aliquot of liver homogenate $(1.0 \mathrm{~mL})$ was mixed with $2 \mathrm{~mL}$ of $0.1 \%$ thiobarbituric acid solution, and heated in a boiling water bath for 15 minutes. The reaction mixture was cooled down to room temperature and centrifuged at $1000 \times \mathrm{g}$ for 10 minutes to obtain a pink colored supernatant. The absorbance of the supernatant was measured at $532 \mathrm{~nm}$ against reagent blanks. TBARS were quantified using a standard curve constructed with 1,1,3,3-tetraethoxypropane.

\section{Reduced Glutathione Contents}

The reduced glutathione (GSH) concentration was measured by a kinetic spectrophotometric method [15]. In short, $0.5 \mathrm{~mL}$ homogenate was precipitated with $5 \%$ trichloroacetic acid (TCA) to remove protein. After centrifugation, $100 \mu \mathrm{L}$ of the clear supernatant was added to tubes containing $2 \mathrm{~mL}$ 5,5-dithiobis(2-nitrobenzoic acid) (0.6 mM in $200 \mathrm{mM}$ phosphate buffer, $\mathrm{pH} 8.0$ ), and the mixture volume was brought to $4.0 \mathrm{~mL}$ with $200 \mathrm{mM}$ phosphate buffer. Absorbance was read at $412 \mathrm{~nm}$ against a solution containing only TCA. Quantification was performed using standard GSH solutions.

\section{Glutathione Reductase Activity}

Glutathione reductase (GR) activity was measured at $340 \mathrm{~nm}$ with a slight modification of the method by Goldberg and Sparner [16]. The reaction mixture contained $50 \mathrm{mM}$ imidazole, $0.3 \mathrm{mM} \mathrm{Na}_{2}$-EDTA, $0.1 \mathrm{mM} \mathrm{NADPH}$ and $2 \mathrm{mM}$ oxidized GSH (GS-SG, pH 7.1).

\section{Glutathione Peroxidase Activity}

Glutathione peroxidase (GPx) activity was measured in accordance with Lawrence and Burk [17]. An aliquot of the hepatic supernatant $(50 \mu \mathrm{L})$ was added to potassium phosphate buffer
(50 $\mathrm{mM}$ ) containing $1 \mathrm{mM}$ EDTA and $1 \mathrm{mM} \mathrm{Na}_{3} \mathrm{~N}$. To the reaction tubes, $0.2 \mathrm{mM}$ NADPH, $1 \mathrm{mM}$ GSH, $1 \mathrm{U}$ GR, $0.25 \mathrm{mM}$ $\mathrm{H}_{2} \mathrm{O}_{2}$ and $1.5 \mathrm{mM}$ cumene peroxide (dissolved in $10 \%$ ethanol initially) were added and absorbance at $340 \mathrm{~nm}$ was kinetically recorded at $25^{\circ} \mathrm{C}$.

\section{Superoxide Dismutase Activity}

SOD activity was measured according to Kakkar et al. [18]. The enzymatic reaction was initiated by incubating $1.0 \mathrm{~mL}$ of liver homogenate with nitroblue tetrazolium, $\mathrm{NADH}$ and phenazine methosulfate for 90 seconds at $30^{\circ} \mathrm{C}$. The reaction was stopped by adding $100 \%$ glacial acetic acid. The color product produced was extracted with $\mathrm{n}$-butanol and absorbance was measured at $520 \mathrm{~nm}$.

\section{Catalase Activity}

CAT activity was assessed by the colorimetric method described by Sinha [19]. For this, $100 \mu \mathrm{L}$ of tissue homogenate was allowed to degrade $200 \mathrm{mM} \mathrm{H}_{2} \mathrm{O}_{2}$ at a ratio of 1:4. The reaction was stopped at 30 seconds intervals by adding $2.0 \mathrm{~mL}$ dichromate-acetate solution (prepared at a 1:3 ratio). The reaction mixture was placed in a boiling water bath for 10 minutes followed by cooling. The developed colored substance was quantified at $620 \mathrm{~nm}$ using $\mathrm{H}_{2} \mathrm{O}_{2}$ standard solutions.

\section{Protein Contents}

The protein contents of the tissue assay samples were assessed according to the method of Bradford with bovine serum albu$\min$ as the standard [20].

\section{Statistical Analysis}

Data are expressed as mean \pm standard deviation. Significant differences among groups were determined using one-way analysis of variance followed by Duncan's test for multiple comparisons [21]. Statistical significance was determined at $p$-value $<$ 0.05 .

\section{Results}

\section{General Parameters}

Table 1 shows the test group design and some parameters measured to estimate the signs of 4-NP induced general toxicity. There was one death out of 60 fish in the $0.1 \mathrm{mg} / \mathrm{kg}$ diet group; this occurred on day 24 of treatment. No mortality occurred in either control or $1.0 \mathrm{mg} / \mathrm{kg}$ diet group. There was a slight retardation of body weight increase after 4 weeks of $1.0 \mathrm{mg} / \mathrm{kg}$ administration. 

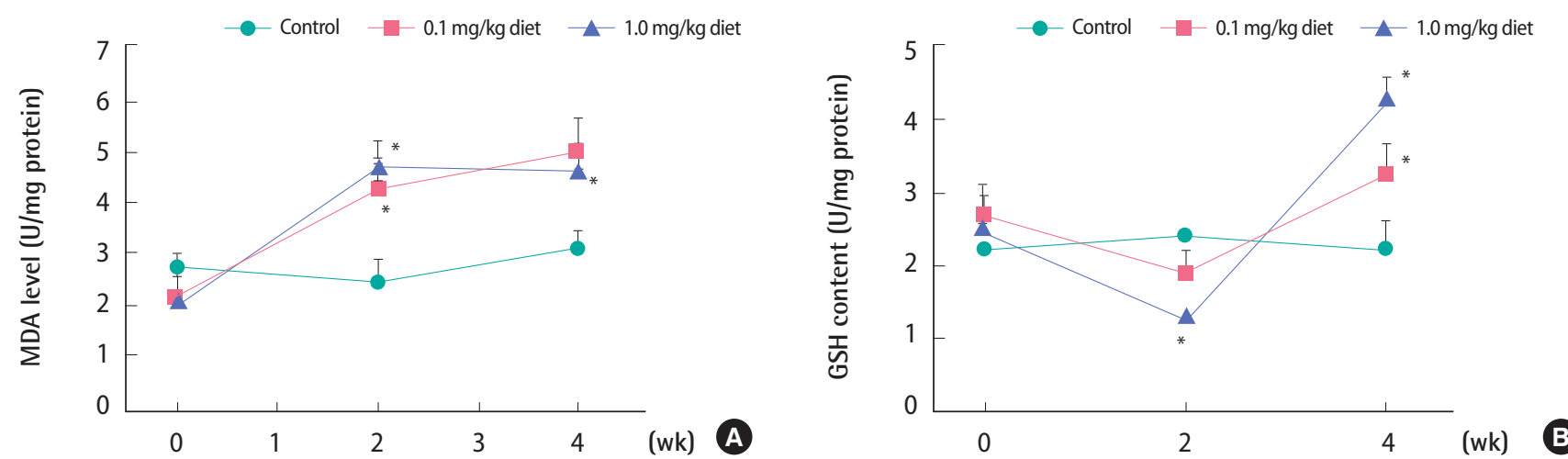

Figure 1. Changes in levels of hepatic (A) malondialdehyde (MDA) and the reduced form of (B) glutathione (GSH) after 4-nonylphenol exposure in Far Eastern catfish. Mean \pm standard deviation $(n=10)$. Statistical comparison was made against control values at the corresponding time points. ${ }^{*} p<0.05$.

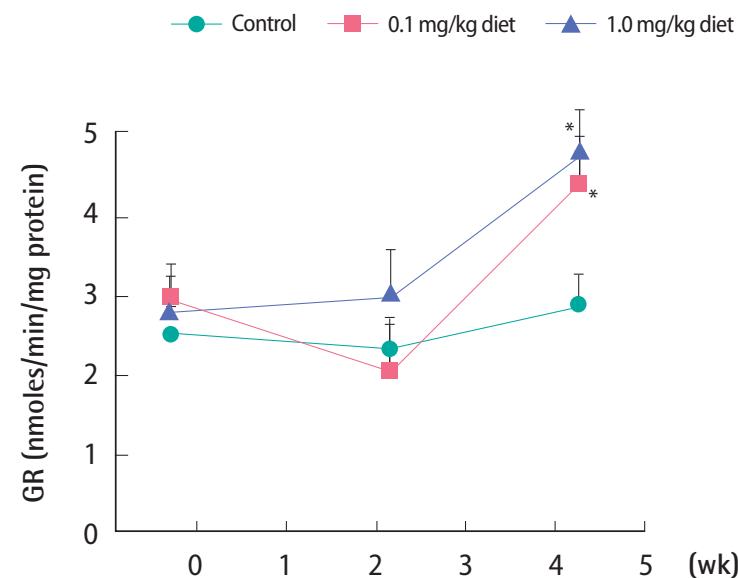

Figure 2. Activity of hepatic glutathione reductase (GR) following 4-nonylphenol exposure in Far Eastern catfish. Mean \pm standard deviation $(n=10)$. Statistical significance was checked against control values at the corresponding time points. ${ }^{*} p<0.05$.

\section{Malondialdehyde Levels}

The hepatic concentration of MDA, which reflects the degree of tissue lipid peroxidation, is illustrated in Figure 1A. There was no significant change in MDA in control catfish throughout the four-week exposure period. However, the MDA level was significantly elevated after two weeks by both 0.1 and $1.0 \mathrm{mg} / \mathrm{kg}$ 4-NP. These elevated levels were similarly maintained throughout four weeks.

Figure 1B shows GSH levels during the four weeks of 4-NP exposure. In the control group, the levels were stable throughout the four-week experimental period. There was a clear tendency for a decrease after two weeks of exposure with the two 4-NP diets: however, statistical significance $(p<0.05)$ was attained with $1.0 \mathrm{mg} / \mathrm{kg}$ but not with $0.1 \mathrm{mg} / \mathrm{kg}(p=0.07)$. At week 4 , GSH levels increased even above the control levels with both the 0.1 and $1.0 \mathrm{mg} / \mathrm{kg} 4-\mathrm{NP}$ diets.

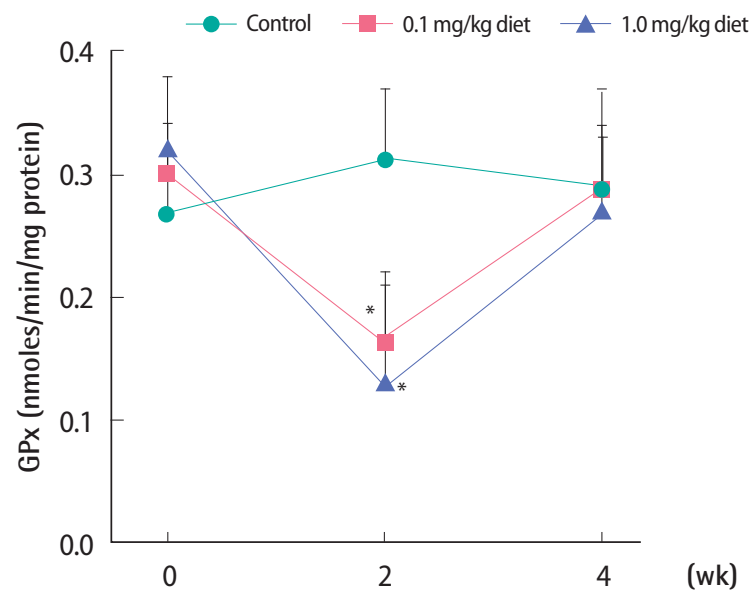

Figure 3. Activity of hepatic glutathione peroxidase (GPX) following 4-nonylphenol exposure in Far Eastern catfish. Mean \pm standard deviation $(n=10)$. Statistical significance was checked against control values at the corresponding time points. ${ }^{*} p<0.05$.

\section{Glutathione Reductase Activity}

Figure 2 illustrates changes in GR activity, the enzyme that reduces the oxidized form of GSH (GS-SG) to the reduced one (GSH), thereby restoring the reduction potential of the cell. The observed pattern shows that there was no substantial change in control livers during the four-week study period. Upon exposure to $0.1 \mathrm{mg} / \mathrm{kg}$ 4-NP, there was no change in the activity within two weeks. However, it increased significantly after four weeks. With the higher level of 4-NP, $1.0 \mathrm{mg} / \mathrm{kg}$, GR activity tended to increase from week 2 (statistically non-significant, $p=0.064$ ) and the level further increased after week 4 .

\section{Glutathione Peroxidase Activity}

GPx was significantly reduced with 4-NP treatment after two weeks at the two tested levels (Figure 3). Such significant decreases recovered completely to control levels by week 4 . 


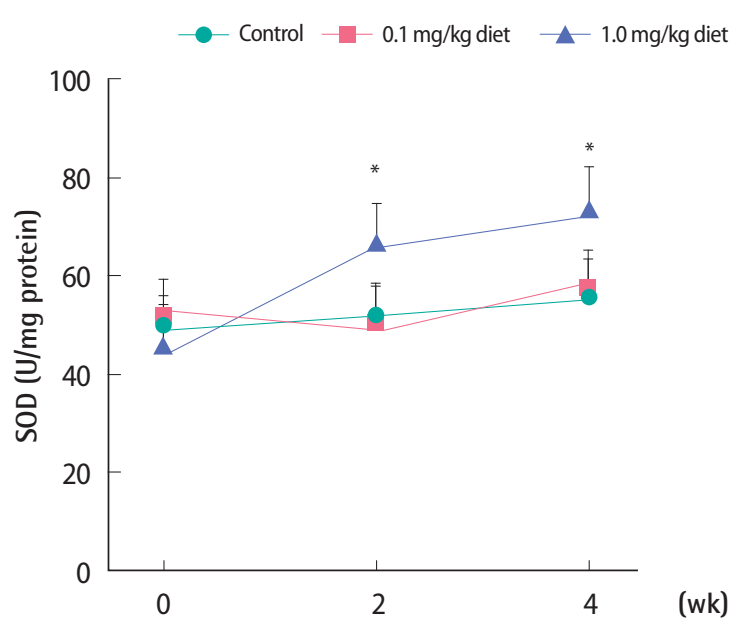

Figure 4. Activity of hepatic superoxide dismutase (SOD) following 4-nonylphenol exposure in Far Eastern catfish. Mean \pm standard deviation $(n=10)$. Statistical significance was checked against control values at the corresponding time points. ${ }^{*} p<0.05$

\section{Superoxide Dismutase Activity}

Changes in SOD activity are illustrated in Figure 4. There was no significant change in SOD activity either in the control or 0.1 $\mathrm{mg} / \mathrm{kg}$ diet fish groups. However with $1.0 \mathrm{mg} / \mathrm{kg} 4-\mathrm{NP}$, SOD increased significantly from week 2 and the elevation was maintained until week 4 .

\section{Catalase Activity}

CAT activity did not change either in the control or $0.1 \mathrm{mg} / \mathrm{kg}$ diet groups throughout the four-week study period. At $1.0 \mathrm{mg} /$ $\mathrm{kg}$ 4-NP, however, a significant increase was noted after four weeks (Figure 5).

\section{Discussion}

This study describes the pro-oxidant effects of 4-NP and the compensatory responses of hepatic anti-oxidant systems, possibly activated to alleviate oxidative stress in the Far Eastern catfish Silurus asotus.

With four weeks of exposure to 4-NP at $1.0 \mathrm{mg} / \mathrm{kg}$, it was observed that normal body weight gain of the fish was slightly retarded. Body weight change is a rough but good indicator of general toxicity in an animal. From the data on instantaneous feed intake with $1.0 \mathrm{mg} / \mathrm{kg}$ 4-NP, which was not different from control, it seems that the reduced body weight gain was the result of reduced feed consumption. The HSI is used to assess hepatic tissue damage or the depletion of energy reserves in the liver. As HSI was not changed by 4-NP, it can be deduced that massive hepatic damage did not occur, even with the higher exposure level. These background data imply that influences iden-

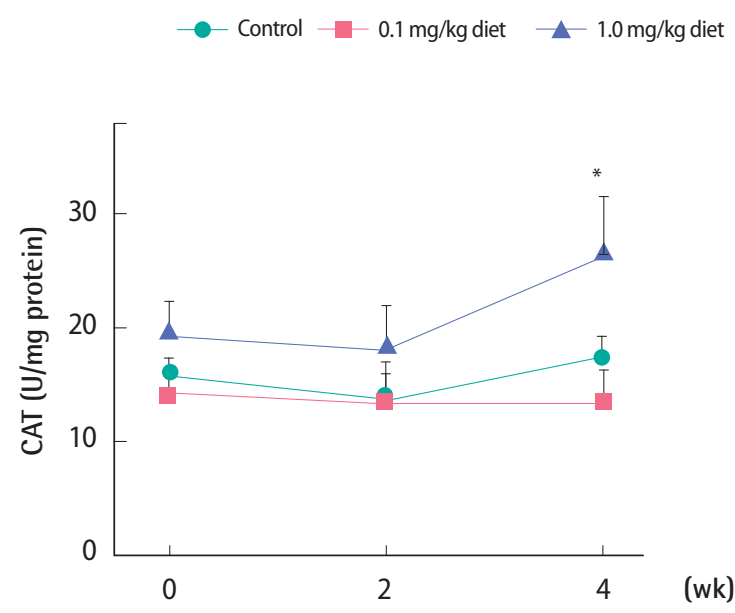

Figure 5. Activity of hepatic catalase (CAT) following 4-nonylphenol exposure to Far Eastern catfish. Mean \pm standard deviation $(n=10)$. Statistical significance was checked against control values at the corresponding time points. ${ }^{*} p<0.05$.

tified in this study were quite specifically ascribable to anti-oxidant systems, rather than to the indirect consequences of the general toxicity of 4-NP.

Of all reported toxicities of 4-NP in animals, malfunction of the endocrine system is the best described [22]. As a possible mechanism for the adverse effects of 4-NP on male reproductive function, accelerated production of ROS was proposed in the mammalian epididymis [11]. In a study by Aly et al. [11], enzyme activities of SOD, CAT and GPx were all decreased in contrast to the increases in most enzymes observed in the current study. It is not clear yet what caused such a discrepancy. Reasons that can be considered include sensitivity differences between species or test dose differences. Very high doses ( $>100 \mathrm{mg} / \mathrm{kg} / \mathrm{d}$ vs. $2-20$ $\mu \mathrm{g} / \mathrm{kg} / \mathrm{d}$ ) of 4-NP were used in the Aly's study [11].

Overall observations from this study indicate that 4-NP is in fact a strong pro-oxidant, and that hepatic enzymes associated with GSH or other anti-oxidant systems seem to operate compensatory mechanisms to overcome the pro-oxidant burden. With the two weeks of exposure, there was a significance increase in lipid peroxidation products (MDA), equally at 4-NP levels of 0.1 and $1.0 \mathrm{mg} / \mathrm{kg}$ diet. Such accelerated lipid peroxides probably led to 4-NP level-dependent consumption of reduced GSH. After four weeks, GSH levels increased over the pre-exposure levels in both exposure groups, indicating the possible activation of compensatory GSH over-production. Interestingly, however, MDA levels at week 4 after 4-NP treatment at both levels did not return to their control levels. This may imply that GSH is not the sole anti-oxidant mechanism mobilized to scavenge 4-NP-induced lipid peroxides. Various anti-oxidant mechanisms, for example vitamin $\mathrm{C}$, vitamin $\mathrm{E}$, and $\alpha$-lipoic acid have 
been reported to control pro-oxidants in cells [23].

It was observed that GR, the enzyme that regenerates GSH by reducing oxidized GSH (GS-SG), was increased within two weeks of exposure, at which time lipid peroxide levels were not recovered to the control state. The enzyme activity of GPx, an enzyme responsible for quenching lipid peroxides, was similarly stimulated by GR in the temporal sense. Other anti-oxidant enzymes examined in this study, SOD and CAT, were also elevated by 4-NP. However, these enzymes seem to be less sensitive to 4-NP than GSH-involving enzymes because those enzymes were stimulated at the $1.0 \mathrm{mg} / \mathrm{kg}$ level, but not at $0.1 \mathrm{mg} / \mathrm{kg}$. Although GR helps produce GSH in principle, elevated enzyme activities of the enzyme will not always result in a net increase of GSH levels. Depending on the balance between the production and consumption of GSH, there could be a decrease in GSH levels even while the enzyme activity is higher [24]. This study did not examine the mechanism of activation of anti-oxidant enzymes after 4-NP administration in catfish. It is presumable, however, that 4-NP might have stimulated the expression of these enzymes. For example, Hernandez et al. [25] demonstrated that 4-NP induces the expression of a series of hepatic cytochrome P450s in mice after seven days of repeated administration. P450 aromatase, responsible for the biosynthesis of estrogens, was also found to be expressed in the whole body of juvenile zebrafish after three days of exposure [26]. In the same line, P450 enzyme genes were expressed when other fish were exposed to 4-NP $[27,28]$.

The findings obtained in this study carry high significance because the 4-NP concentrations administered to our experimental fish were very low in comparison with those reported by others. For example, most studies have delivered 4-NP in the range of milligrams to several hundred milligrams per kilogram body weight [29]. In comparison, the current study tested 0.1 and 1.0 $\mathrm{mg} / \mathrm{kg}$ diet which corresponds to 2 and $20 \mu \mathrm{g} / \mathrm{kg}$ body weight (Table 1). It is highly plausible that such low level exposure can occur through commercial fish feed or ambient culture water. It should be borne in mind that 4-NP is detected ubiquitously in wild fishes which could be major resources for commercial fish feeds $[29,30]$.

MDA levels were elevated after two weeks, along with compensatory anti-oxidant enzyme systems. Such systems seem indicate the activation of anti-oxidative mechanisms over time, because MDA concentrations leveled off after four weeks. These biochemical alterations observed in Far Eastern catfish could be useful as biomarkers to deduce prior exposure to 4-NP. There was a clear difference in the kinetics and also the sensitivity for the activation of individual enzymes, with some parameters responding earlier than others.

\section{Acknowledgements}

This work was financially supported by the Faculty Research Funds of Kunsan National University in the fiscal year 2014.

\section{Conflict of Interest}

The author has no conflict of interest with the material presented in this paper.

\section{References}

1. Soverchia L, Ruggeri B, Palermo F, Mosconi G, Cardinaletti G, Scortichini $G$, et al. Modulation of vitellogenin synthesis through estrogen receptor beta- 1 in goldfish (Carassius auratus) juveniles exposed to 17-beta estradiol and nonylphenol. Toxicol Appl Pharmacol 2005;209(3):236-243.

2. Lacorte S, Raldúa D, Martínez E, Navarro A, Diez S, Bayona JM, et al. Pilot survey of a broad range of priority pollutants in sediment and fish from the Ebro river basin (NE Spain). Environ Pollut 2006;140(3):471-482.

3. European Chemicals Agency. Support document for identification of 4-nonylphenol, branched and linear, ethoxylated [cited 2015 May 29]. Available from: http://echa.europa.eu/documents/10 162/14598345/support_document_4-nonylphenol+ethoxylat es_20130612_en.pdf.

4. Ahel M, McEvoyJ, Giger W. Bioaccumulation of the lipophilic metabolites of nonionic surfactants in freshwater organisms. Environ Pollut 1993;79(3):243-248.

5. Pomatto V, Palermo F, Mosconi G, Cottone E, Cocci P, Nabissi M, et al. Xenoestrogens elicit a modulation of endocannabinoid system and estrogen receptors in 4NP treated goldfish, Carassius auratus. Gen Comp Endocrinol 2011;174(1):30-35.

6. Jobling S, Sumpter JP. Detergent components in sewage effluent are weakly oestrogenic to fish: an in vitro study using rainbow trout (Oncorhynchus mykiss) hepatocytes. Aquat Toxicol 1993;27(34):361-372.

7. White R, Jobling S, Hoare SA, Sumpter JP, Parker MG. Environmentally persistent alkylphenolic compounds are estrogenic. Endocrinology 1994;135(1):175-182.

8. Xu H, Yang M, Qiu W, Pan C, Wu M. The impact of endocrinedisrupting chemicals on oxidative stress and innate immune response in zebrafish embryos. Environ Toxicol Chem 2013;32(8): 1793-1799.

9. Jayakanthan M, Jubendradass R, D'Cruz SC, Mathur PP. A use of homology modeling and molecular docking methods: to explore binding mechanisms of nonylphenol and bisphenol A with antioxidant enzymes. Methods Mol Biol 2015;1268:273-289.

10. Chen BS, Yen JH. Effect of endocrine disruptor nonylphenol on physiologic features and proteome during growth in Arabidopsis thaliana. Chemosphere 2013;91(4):468-474.

11. Aly HA, Domènech O, Banjar ZM. Effect of nonylphenol on male reproduction: analysis of rat epididymal biochemical markers and 
antioxidant defense enzymes. Toxicol Appl Pharmacol 2012; 261(2):134-141.

12. Choi MS, Park HJ, Oh JH, Lee EH, Park SM, Yoon S. Nonylphenol-induced apoptotic cell death in mouse TM4 Sertoli cells via the generation of reactive oxygen species and activation of the ERK signaling pathway.J Appl Toxicol 2014;34(6):628-636.

13. Kim KD, Kim JD, Lim SG, Kang YJ, Son MH. Effects of dietary lipid sources on the growth and body composition of the far eastern catfish, Silurus asotus. Korean J Fish Aquat Sci 2010;43(5): 445-450 (Korean).

14. Ohkawa H, Ohishi N, Yagi K. Assay for lipid peroxides in animal tissues by thiobarbituric acid reaction. Anal Biochem 1979;95(2): 351-358.

15. Ellman GL. Tissue sulfhydryl groups. Arch Biochem Biophys 1959;82(1):70-77.

16. Goldberg DM, Sparner RJ. Glutathione reductase. In: Bergmeyer HU, Bergmeyer J, Grassl M, Moss DW, editors. Methods of enzymatic analysis. 3rd ed. Weinheim: Verlag Chemie; 1987, p. 258 265.

17. Lawrence RA, Burk RF. Glutathione peroxidase activity in selenium-deficient rat liver. 1976. Biochem Biophys Res Commun 2012;425(3):503-509.

18. Kakkar P, Das B, Viswanathan PN. A modified spectrometric assay for superoxide dismutase. Indian J Biochem Biophys 1984;21(2): 130-132.

19. Sinha AK. Colorimetric assay of catalase. Anal Biochem 1972; 47(2):389-394.

20. Bradford MM. A rapid and sensitive method for the quantitation of microgram quantities of protein utilizing the principle of protein-dye binding. Anal Biochem 1976;72:248-254.

21. Duncan DB. Multiple range and multiple F tests. Biometrics 1955;11(1):1-42.

22. Palermo FA, Mosconi G, Angeletti M, Polzonetti-Magni AM. As- sessment of water pollution in the Tronto River (Italy) by applying useful biomarkers in the fish model Carassius auratus. Arch Environ Contam Toxicol 2008;55(2):295-304.

23. Jaeschke H. Antioxidant defense mechanisms. In: McQueen CA, editor. Comprehensive toxicology. 2nd ed. Oxford: Elsevier; 2010, p. 319-337.

24. Meng SL, Chen JZ, Hu GD, Song C, Fan LM, Qiu LP, et al. Effects of chronic exposure of methomyl on the antioxidant system in liver of Nile tilapia (Oreochromis niloticus). Ecotoxicol Environ Saf 2014;101:1-6.

25. Hernandez JP, Chapman LM, Kretschmer XC, Baldwin WS. Gender-specific induction of cytochrome P450s in nonylphenol-treated FVB/NJ mice. Toxicol Appl Pharmacol 2006;216(2):186-196.

26. Kazeto Y, Place AR, Trant JM. Effects of endocrine disrupting chemicals on the expression of CYP19 genes in zebrafish (Danio rerio) juveniles. Aquat Toxicol 2004;69(1):25-34.

27. Cocci P, Mosconi G, Palermo FA. Effects of 4-nonylphenol on hepatic gene expression of peroxisome proliferator-activated receptors and cytochrome P450 isoforms (CYP1A1 and CYP3A4) in juvenile sole (Solea solea). Chemosphere 2013;93(6):1176-1181.

28. Meucci V, Arukwe A. The xenoestrogen 4-nonylphenol modulates hepatic gene expression of pregnane $\mathrm{X}$ receptor, aryl hydrocarbon receptor, CYP3A and CYP1A1 in juvenile Atlantic salmon (Salmo salar). Comp Biochem Physiol C Toxicol Pharmacol 2006;142(12):142-150.

29. Ying GG, Kookana RS, Dillon P. Sorption and degradation of selected five endocrine disrupting chemicals in aquifer material. Water Res 2003;37(15):3785-3791.

30. Van Leeuwen S, De Boer J; Netherlands Institute for Fisheries Research. Detecting organic contaminants in food: the case of fish and shellfish. In: Watson DH, editor. Pesticide, veterinary and other residues in food. Cambridge: Woodhead Pub.; 2004, p. 536-576. 